\title{
Evolutionary Aspects of Acaricide-Resistance Development in Spider Mites
}

\author{
Masahiro (Mh.) Osakabe, ${ }^{1}$ Ryuji Uesugi, ${ }^{1}$ and Koichi Goka ${ }^{2}$ \\ ${ }^{1}$ Laboratory of Ecological Information, Graduate School of Agriculture, Kyoto University, Kyoto 606-8502, Japan \\ ${ }^{2}$ Invasive Alien Species Research Team, National Institute for Environmental Studies, Tsukuba 305-8506, Japan \\ Correspondence should be addressed to Masahiro (Mh.) Osakabe, mhosaka@kais.kyoto-u.ac.jp
}

Received 2 September 2009; Accepted 29 December 2009

Recommended by Barry Pittendrigh

\begin{abstract}
Although the development of acaricide resistance in spider mites is a long-standing issue in agricultural fields, recent problems with acaricide resistance may be characterized by the development of complex- and/or multiresistance to acaricides in distinct classes. Such complexity of resistance is not likely to be a single mechanism. Pesticide resistance involves the microevolution of arthropod pests, and population genetics underlies the evolution. In this review, we address the genetic mechanisms of acaricide resistance evolution. We discuss genetic diversity and linkage of resistance genes, relationships between mite habitat and dispersal, and the effect of dispersal on population genetic structure and the dynamics of resistance genes. Finally, we attempt to present a comprehensive view of acaricide resistance evolution and suggest risks under globalization as well as possible approaches to managing acaricide resistance evolution or emergence.
\end{abstract}

Copyright (C) 2009 Masahiro (Mh.) Osakabe et al. This is an open access article distributed under the Creative Commons Attribution License, which permits unrestricted use, distribution, and reproduction in any medium, provided the original work is properly cited.

\section{Introduction}

Safe and sufficient agricultural production is one of the most important global issues of the 21st century. Along the demands of food safety and minimizing environmental impacts, the idea of pest management is rapidly moving from chemical control toward sustainable technologies involving the exploitation of ecological functions. Nevertheless, insect pests and diseases cause huge yield losses in crops production, and pesticides have played an important role in mitigating yield loss of agricultural produce. Considering that the occurrence and geographical distribution of pests may change with global warming and economic globalization, pesticides will continue to be important in future agricultural production.

However, repeated pesticide use results in microevolution due to the selection pressure ultimately leading to resistance development. Marked development of acaricide resistance has been found in spider mites (Acari: Tetranychidae), which have short generation and high propagation potential. Since the 1990s, many populations of the two-spotted spider mite, Tetranychus urticae Koch, and the European red mite, Panonychus ulmi (Koch), have developed global resistance against many new acaricides. Among the top 20 resistant agricultural and medical arthropod pests, ranked by number of unique compounds in Arthropod Pesticide Resistance Database (http://www.pesticideresistance.org/), the most resistance has developed in T. urticae, whereas $P$. ulmi is the ninth most resistant [1].

Recent acaricide resistance problems are characterized by the development of complex- and/or multiresistance to acaricides in distinct classes. Pleiotropic effects may explain multiresistance in that a single key factor, for example, transacting factors, confers resistance to multiple insecticides involving distinct classes via a simultaneous increase in the action of several metabolic mechanisms involved in resistance [2]. Similarly, acaricide selection frequently confers cross resistance to acaricides in the distinct classes on spider mites, for example, T. urticae [3, 4] and P. ulmi [5]. However, the mechanisms of such resistance are largely unknown.

The complexity of acaricide resistance found today may not be explained by a single mechanism. Tetranychus urticae is a ubiquitous species that vigorously attacks an enormous number of plant species. Cross-resistance and the inheritance 
of resistance are not necessarily common to localities in this mite. These findings suggest that each selection process possibly leads to a different type of resistance mechanism, depending on the location and past selection history, and may yield different cross-resistance patterns.

Pesticide-resistance development is an example of microevolution in arthropod pests. Population genetics, which is affected by many factors including biological and ecological traits of arthropod pests, properties of pesticides, and pesticide application patterns [6-8], underlies the evolution. In this review, we address genetic mechanisms during the process of acaricide resistance evolution and discuss features of resistance genes and their genetic linkage, relationships between habitat and mite dispersal, and the effect of dispersal on population genetic structure and the dynamics of resistance genes to gain insight into spider mite resistance management in the global physical distribution environment. Finally, we comprehensively evaluate the evolution of acaricide resistance and suggest the global risks and management prospects.

\section{Aspects and Features of Acaricide Resistance}

Today's acaricide resistances assume a new complicated aspect rather than the past; that is, genetic mode of resistance is regionally different. Etoxazole resistance is inherited maternally in Korean T. urticae populations [9], implying that it is caused by a mutation in cytoplasmic mitochondrial DNA. In contrast, in Japanese populations, the etoxazole resistance locus is located on a nuclear chromosome [10]. Hexythiazox resistance is under monogenic control in Australian populations [11], whereas more than one locus is involved in Japanese populations [10]. Similarly, chlorfenapyr resistance in Belgian populations is under polygenic control $[12,13]$, but Japanese populations might have a resistant allele at only one of the possible chlorfenapyr resistance loci (monogenic) [14]. Moreover, while clofentezine resistance confers a high level of crossresistance to hexythiazox [15] but not to etoxazole in Australia, hexythiazox resistance probably confers etoxazole resistance in Japanese local populations [10, 16]. Crossresistance has not been reported between etoxazole and hexythiazox $[17,18]$.

Monogenic resistance is favored under field selection regimes [19-21], and acaricide resistance is typically monogenic $[11,22-24]$, although some instances of polygenic resistance have been reported [25-27]. However, each polygenic allele for chlorphenapyr and hexythiazox resistance may be capable of conferring substantial resistance $[10,12$, 13]. Previous standard polygenic inheritance descriptions likely cannot adequately predict the evolutionary process of this type of inheritance in which several or a few resistance genes have additive and major effects on the resistant phenotype. In this regard, the $\mathrm{LC}_{50}$ for hexythiazox is notably higher for polygenic resistance in Japan $\left(>10,000 \mathrm{mg} \mathrm{L}^{-1}\right)$ [10] than for monogenic resistance in Australia $\left(48 \mathrm{mg} \mathrm{L}^{-1}\right)$ [11], whereas similar $\mathrm{LC}_{50}$ values for chlorfenapyr were reported in a Japanese resistant population $\left(2,130 \mathrm{mg} \mathrm{L}^{-1}\right)$

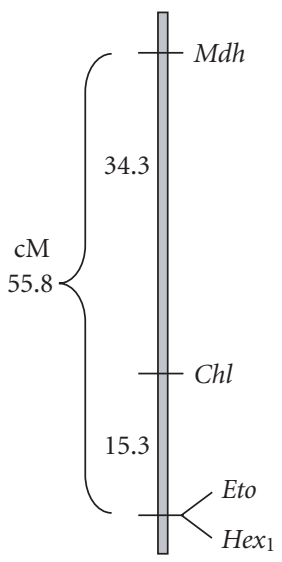

Figure 1: Gene map of a linkage group of loci for malate dehydrogenase $(\mathrm{Mdh})$, resistance to chlorfenapyr $(\mathrm{Chl})$, etoxazole (Eto), and hexythiazox $\left(\right.$ Hex $\left._{1}\right)$ in T. urticae.

[14] and a Belgian resistant population $\left(2,939 \mathrm{mg} \mathrm{L}^{-1}\right)$ [12]. Moreover, the potential for each resistance gene is individually associated with other distinctive resistance genes.

\section{Genetic Linkage among Acaricide Resistance Genes}

Most spider mite species have arrhenotokous parthenogenesis; males develop from unfertilized eggs (haploid), and females develop from fertilized eggs (diploid) [28]. This type of parthenogenesis may favor the fixation of fewer but more advantageous alleles $[29,30]$ but see $[31,32]$ such as acaricide resistance alleles under acaricide application. Fast fixation of advantageous alleles in male haploids may result in rapid fixation of linked alleles [33], as in the hitchhiking effect $[34,35]$.

To date, little is known about the genetic linkages among acaricide resistance genes. Uesugi et al. [14] revealed that $T$. urticae etoxazole and chlorfenapyr resistance genes are genetically linked to each other with a recombination rate of $14.8 \%(15.3 \mathrm{cM})$ using the three-point cross with malate-dehydrogenase allozymes [36] and located at 55.8 and $34.3 \mathrm{cM}$ from loci accompanying etoxazole and chlorfenapyr resistance, respectively (Figure 1). They predicted the probability of hitchhiking effects between two closely linked acaricide resistance genes under acaricide selection, calling this phenomenon "apparent cross-resistance." Although hexythiazox resistance is under monogenic control in Australian T. urticae populations, Asahara et al. [10] demonstrated that more than one locus is involved in hexythiazox resistance in a Japanese T. urticae population. Moreover, they found that one of the loci associated with hexythiazox resistance was tightly or completely linked to the etoxazole resistance locus (Figure 1). This suggests that the development of hexythiazox resistance possibly conferred etoxazole resistance in a Japanese local population of $T$. urticae that had never been exposed to etoxazole application [16]. 
Construction of a genetic linkage map is helpful to determine the effects of genetic relationships among loci associated with distinct acaricides, including the hitchhiking effects during the development of acaricide resistance, as Yan et al. [37] analyzed in yellow fever mosquitoes, Aedes aegypti (L.) (Diptera: Culicidae). Genetic markers, especially microsatellites, should be useful tools for genetic mapping of resistance genes. A substantial number of microsatellites have been cloned and analyzed in spider mites, including the citrus red mite Panonychus citri (McGregor) [38], T. urticae [39-41], and the Kanzawa spider mite Tetranychus kanzawai Kishida [42]. Microsatellites have also been applied to kin species such as Tetranychus turkestani (Ugarov and Nikolskii) [43]. We conduct a linkage analysis of these microsatellites and have revealed two (12 loci) and three (14 loci) linkage groups in T. urticae and T. kanzawai, respectively (Uesugi et al. unpublished data, Matsuo et al. unpublished data). A linkage map with higher resolution should be complete in the near future.

\section{Breeding Patch and Genetic Differentiation}

Incidental factors such as gene flow (migration rate) and founder effects affect the dynamics of the local frequency of resistance genes in a metapopulation. Follett and Roderick [44] demonstrated that several resistance foci formed in a metapopulation through model analyses in which migration followed a two-dimensional stepping-stone model under the assumption that individuals move only to neighboring subpopulations in a latticed distribution and a percentage of the populations go extinct at each generation. Spider mites are tiny, wingless arthropods. They exhibit two major dispersal behaviors, crawling and aerial dispersal [45-47]. Crawling is assumed to be used over short distances, such as between leaves within a plant, whereas aerial dispersal may be used for longer distance migration.

We addressed spider mite movement and breeding patches on a host plant because there is some evidence of sibmating in Tetranychus spider mites: a fertilized female deposits many eggs on the same leaf and very little migration occurs during development under uncrowded conditions [48-52]. Hinomoto and Takafuji $[53,54]$ studied the genetic structure of a T. urticae population on strawberries based on phosphoglucoisomerase allozyme frequency [36]. Interestingly, they found the highest level of genetic differentiation, as measured by the fixation index $\left(F_{S T}\right)$ [55], at the smallest habitat (leaflet) level. $F_{S T}$ decreased with increasing the habitat size, that is, leaflet $>$ leaf $>$ plant $[53,54]$. In contrast, the value of the inbreeding coefficient $\left(F_{I S}\right)$ [55] was the highest at the largest habitat level (subdivided section in the strawberry beds) and the lowest at the smallest habitat level (leaflets) [53]. In this regard, the Wahlund effect probably became larger in larger habitat sizes pooled for $F$ statistics analyses. Therefore, such genetic structure implies that although T. urticae females and males randomly mate on breeding patches (leaflets), gene flow among the patches is limited. The tendency to form breeding patches probably increases when population densities are low $[50,52]$ and such genetic structure may often cause genetic differentiation among breeding patches through random genetic drift and/or founder effects.

Adult $P$. citri females are rather mobile; their microhabitat is greenish twigs with foliage in citrus orchards and the females deposit their eggs on plural leaves [56]. Osakabe and Komazaki [57] focused on the genetic structure in a limited habitat area and performed several laboratory experiments with small citrus seedlings using esterase locus $(\alpha$-Est1) alleles [58]. They introduced females from two $P$. citri strains, in which the $\alpha$-Est 1 locus was fixed to distinct alleles on the small citrus seedlings, and analyzed phenotype frequencies. As a result, although the inbreeding coefficients within a seedling decreased with population increase, the inbreeding coefficients remained substantially higher than zero even after the mite population had expanded enough to overlap the introduced colonies. Panonychus citri may couple randomly by nature, at least within the smallest breeding patch of a single leaf [57]. Despite their expected mobility [56], adult $P$. citri females oviposited on very few leaves, at least when the population density was low, and most individuals stayed on the leaves where they had been oviposited during the juvenile developmental stages in the experiments by Osakabe and Komazaki [57].

Adult males usually guard quiescent deutonymphal females and copulate with newly emerged females immediately after their last molts [59]. Once the first copulation for a virgin female has been completed, subsequent mating with other males is ineffective $[60,61]$. Many offspring mature on the same leaf, at least during low population density. These spider mite habits might facilitate founder effect in each breeding patch and influence preservation (or fixation) of rare genes, such as acaricide resistance genes.

Under a condition of no acaicide selection, Uesugi et al. [62] demonstrated that genetic drift also works on the dynamics of an acaricide resistance allele; they found a remarkable decrease in mortality following an etoxazole application in two of 32 experimental subpopulations isolated for 13 generations, whereas the resistance did not develop in another 64 subpopulations that experienced limited gene flow.

\section{Dispersal Depending on Habitat Structures and Environments}

Dispersal behavior, colonization, and the resulting population structure of spider mites should strongly affect the distribution and spread of acaricide resistance genes [63]. Because of vigorous reproduction, spider mites cause leaf and plant deterioration, resulting in both food shortage and desiccation $[64,65]$. Such unfavorable conditions motivate dispersal behaviors.

Dispersal, which is an important event for settlement of new habitats $[63,66-68]$, may be affected by the surroundings of microhabitats that may vary depending on the agricultural system, for example, between woody and herbaceous plants and between greenhouse and field situations. This should result in genetic structure diversity of each local population and a consequent geographic distribution of alleles. Goka and Takafuji [69] found that 
Japanese T. urticae populations on fruit trees and roses could be subdivided into three geographical groups based on allozyme loci allele frequencies, whereas no particular geographical patterns were detectable in populations that inhabited annually herbaceous crops.

\subsection{Dispersal and Genetic Differentiation in Greenhouses.} Most local populations on herbaceous crops occur only temporarily. Thus a population increase may begin by invasion of a small number of mites, facilitating founder effects and genetic differentiation between local populations even if their host plants are adjacently located $[69,70]$. Particularly under greenhouse conditions, population growth on herbaceous crops usually starts with a small number of immigrants. They may often experience an intensive bottleneck due to acaricide application in a closed place. This is also the case for greenhouse-grown perennial plants such as roses, although spider mites may maintain their populations on host plants throughout the year. Spider mites are unlikely to use aerial dispersal by means of wind-borne in a greenhouse due to the calm conditions. Windborne dispersal requires adequate wind velocity of $1.5 \mathrm{~m} / \mathrm{s}$ or more [71-73]. Instead, dispersal by crawling or passive transportation by human movements through agricultural practices is expected in greenhouses [40].

Under such restricted dispersal conditions, genetic differentiation is likely to occur among greenhouse colonies, especially at low population densities [50, 52]. Hinomoto and Takafuji [53] found significant genetic differentiation in a $T$. urticae population on greenhouse strawberries $\left(F_{S T \text { between sites }}=0.16, F_{S T}\right.$ between plants $\left.=0.35\right)$. Tsagkarakou et al. [70] investigated population structures in greenhouses in France, where roses, carnations, egg plants, and tomatoes were cultivated. They also found significant differentiation within a greenhouse $\left(F_{S T \text { between sites }}=0.01-0.33\right)$. In contrast, Navajas et al. [40] obtained low estimates of $F_{S T}$ (0.008-0.09). Nevertheless, the latter findings may not contradict the former examples. Navajas et al. [40] sampled mites from areas incontrovertibly wider than the breeding colony ranges; for example, 15 eggplants were sampled from each site ( $25 \mathrm{~m}$ long transects), and two females per plant were used for the analysis. Such sampling strategies might obscure the effects of genetic differentiation among breeding patches on the population genetic structure data. However, their data demonstrated a general trend toward significant heterozygote deficiency [40], suggesting a Wahlund effect due to substantial isolation of the mite population into smaller breeding patches.

Uesugi et al. [74] analyzed the fine-scaled genetic structure of $T$. urticae exposed to more than one acaricide heavily applied to rose trees in a greenhouse. They set 18 consecutive quadrats (length: $1.2 \mathrm{~m}$ ) in two beds (lengths: 22 and $27 \mathrm{~m}$ ) in a greenhouse and analyzed the genetic structure using microsatellites. As a result, the level of genetic differentiation $(\theta)$ [75] among quadrats was higher in the bed with lower mite density $(0.221-0.34)$ than in that with higher mite density (0.134-0.14) [74]. An analysis of molecular variance (AMOVA) revealed a temporal change in allelic frequencies in the bed with lower mite density $(P<$
.001), but not in that with higher mite density [74]. These differences likely reflect the larger genetic drift at lower mite density; small population size could cause strong genetic drift, thereby decreasing genetic variation, which is indexed by allelic richness and heterozygosity, and increasing genetic differentiation among quadrat populations $[76,77]$. Uesugi et al. [74] found that isolation-by-distance [78], calculated by comparing the $F_{S T} /\left(1-F_{S T}\right)$ values with the spatial distance of each quadrat population [79], was significant in the bed with higher mite density (Mantel test, $P<.05$ ) but not in that with lower mite density. A significant positive autocorrelation was detected by spatial autocorrelation analysis [80] only within a short range $(2.4-3.6 \mathrm{~m})$ of the bed with higher mite density, suggesting that migration was limited to a short range, whereas larger-scale dispersal, such as aerial dispersal, did not appear to contribute to the genetic structure [74].

Spider mites within a breeding patch are likely to mate randomly rather than assortatively, and an increase in population density effectively reduces $F_{S T}$ values among patches $[54,57]$. Nevertheless, fine-scale genetic structure is preserved under stable environments such as a perennial host plant in a greenhouse [74]. Yano [81] demonstrated collective dispersal and resulting aggregation at a new feeding site in T. urticae; crawling dispersers tended to follow the trails of former dispersers, which may be associated with the threads spun by spider mites. Therefore, the tendency for high $F_{I S}$ values in greenhouse spider mites may be attributed to the traits of spider mites forming breeding patches on small habitats, such as an individual leaf, and the limitation of immigration among patches. Consequently, gene flow between breeding patches is delayed even if mites are located on the same plant. Instead, founder effects and genetic drift promote genetic differentiation between breeding patches via fixation to specific alleles in each breeding patch.

5.2. Aerial Dispersal Mode and Gene Flow in Orchards and Citrus Groves. Spider mites aerially disperse by means of wind-borne or ballooning. Young gravid adult females are the dominant dispersers in both aerial dispersal means $[82,83]$. However, species that exploit the wind-borne and ballooning probably achieve different arrival distances. In a practical investigation, dispersal of only 10-20 m occurred from blackberry into corn $[66,71]$. Model analyses have suggested 5.5-12 $\mathrm{m}$ and $16-48 \mathrm{~m}$ dispersal from corn and apple, respectively [84]. In peanut field experiments by Boykin and Campbell [71], regardless of release height for aerial dispersal, most T. urticae caught by sticky traps were only $60 \mathrm{~cm}$ above the ground (the lowest traps) and catch numbers decreased as the traps were set higher (the highest traps were set $2.1 \mathrm{~m}$ above the ground). Therefore, as a general rule for the passive aerial ground dispersal, the number of arrivals per unit area probably declines steeply with increasing distance from the point of departure [85]. In contrast, in the field experiments by Fleschner et al. [82], ballooning O. punicae were captured at the top $60 \mathrm{~cm}$ of a $6 \mathrm{~m}(5 \times 5 \mathrm{~cm})$ pole in an avocado grove, suggesting that they drifted upward after takeoff and that mites dispersing by ballooning migrate longer distances than do windborne mites. In fact, $P$. citri has been observed aerially migrating 
between adjacent citrus groves [82] and from distant citrus groves to Japanese pear orchards [86]. Almost imperceptible air currents are sufficient for mites to balloon [82].

Uesugi et al. [87] investigated the structures of T. urticae populations in two apple orchards using five microsatellite loci. In the first orchard, apple trees were planted in lines at intervals of 5-8 $\mathrm{m}$, and their branches did not contact neighboring trees. In the second orchard, apple trees were planted at intervals of 2 and $7.5 \mathrm{~m}$ within and between lines, respectively. To exclude effects on gene flow from direct crawling dispersal between apple trees, Uesugi et al. sampled mites from apple trees along a diagonal transect in the second orchard. Ultimately, mites were collected from apple trees separated by distances of 10-24 $\mathrm{m}$ within about $100 \mathrm{~m}$ of the lines in these orchards. As a result, heterozygote deficiency (f) [75] and $\theta$ among trees were positive in these orchards ( $f=0.328$ and $\theta=0.028$ in the first orchard, and $f=$ 0.078 and $\theta=0.012$ in the second orchard). This suggests that there was a certain level of limitation to mite migration, and complete genetic homogenization was prevented within a scale of the studied sites. Nevertheless, analyses of genetic similarity and spatial location using dendrograms, isolation-by-distance, and multiallelic correlograms revealed no significant genetic differentiation among trees in these orchards. This may be explained that the level of gene flow is relatively high over long distances of $<100 \mathrm{~m}$, resulting in no genetic structure among mite populations in distant trees. Similarly, Grafton-Cardwell et al. [63] found that the frequencies of T. urticae and Tetranychus pacificus McGregor resistant to cyhexatin and dicofol were equivalent in on neighboring almonds and cotton, although cyhexatin had been applied only on almonds while dicofol had been applied only on cotton, indicating the occurrence of substantial gene flow between mite populations on these plants by aerial dispersal. Notwithstanding, significant isolation-bydistance was found in an analysis of wider geographic scales (populations were $10 \mathrm{~m}$ to more than $100 \mathrm{~km}$ apart) using allozymes in Greece [88]. Those suggest limitations for this mite to regionally disperse using the wind.

Genetic differentiation among geographically distant populations was also found in P. citri. Osakabe et al. [89] analyzed $P$. citri genetic structure hierarchically from the level between patches within a tree to between regions (Honshu and Kyushu islands of Japan), using the coefficient of gene differentiation $\left(G_{S T}\right)[90,91]$. They found that $G_{S T}$ tended to be smaller with decreasing area and distance between populations [89]. This geographic trend was consistent with the results of a protein analysis by Osakabe and Sakagami [92]. However, the diversity of $P$. citri populations within a local population and/or a microhabitat was different from that of T. urticae, which maintained frequent gene flow in a local population $[87,93]$. The divergence within a grove and/or a tree clearly accounted for the total diversity of $P$. citri populations; $G_{S T}$ values between trees within a grove and between patches within a tree were larger than those between groves. These results suggest that $P$. citri frequently migrates between citrus groves within a locality but not across wider areas. Moreover, higher diversity among trees (or patches) within groves than between groves implies that this mite migrates mainly by aerial drift (ballooning) between groves [82], whereas crawling dispersal is limited. Thus interbreeding between patches is infrequent and solely dependent on interpatch distance [57].

Consequently, the two modes of aerial dispersal in spider mites, wind-borne and ballooning, likely result in widely different population structures. Dispersion patterns of species exploiting the wind-borne might be explained using an aerodynamic model, such as the seed flux model $[94,95]$, as described by Jung and Croft [84]. These patterns may represent a practical decline in the number of arrivals per unit area with increasing distance from departure point [85]. The significance of microhabitat for $P$. citri genetic population structures was also demonstrated in marine organisms with reduced dispersal, such as polychaetes, which disperse only during the planktonic larval stage [96].

\section{Effects of Dispersal and Habitat Stability on Acaricide Resistance Development}

Patch size and persistence of host plants may largely influence population biology as well as gene flow between patches (colonies) and/or local populations. Additionally, variation in the initial frequency of pesticide resistance genes and intensity of selection force by pesticide application may result in different pesticide resistance development rates among local pest populations [97], which may need to be considered to determine the velocity of acaricide resistance development and prevalence $[19,98-100]$.

As described above, T. urticae populations inhabiting stable woody plant habitats (fruit trees and roses) were geographically differentiated into genetically structured groups in Japan, but such differentiation did not occur in populations inhabiting annual herbaceous crops [69]. Goka [101] assessed resistance to two acaricides, pyridaben and fenpyroximate (used in Japan since 1991), in T. urticae populations collected from 48 deciduous fruit tree orchards and rose gardens and from 42 patches of herbaceous plants (some of which had been grown in greenhouses) from spring 1993 to autumn 1994. They found a rapid development of acaricide resistance in the woody plant populations. Only 7 and 8 of 48 populations showed $100 \%$ mortality after the application of pyridaben $\left(200 \mathrm{mgl}^{-1}\right)$ and fenpyroximate $\left(50 \mathrm{mgl}^{-1}\right)$, respectively. In contrast, resistant individuals were found in more than $80 \%$ of the populations; more than half of the tested individuals were alive in 24 and 10 populations after the application of pyridaben and fenpyroximate, respectively. Remarkably, no individual died by either acaricide in six populations (Figures 2(a) and 2(b)). In contrast, resistant individuals were found in a few populations after application of the acaricides, and more than $50 \%$ of individuals survived in an identical population (Figures 2(c) and 2(d); arrows). Different velocities of resistance development between these habitats were not caused by differences in the frequency of acaricide application (Figure 3). Instead, these phenomena may have occurred due to differences in mite population size which can be harbored in the habitat and habitat stability. Mite populations on woody plants are stable residents such that gene flow between them results in the strong likelihood 


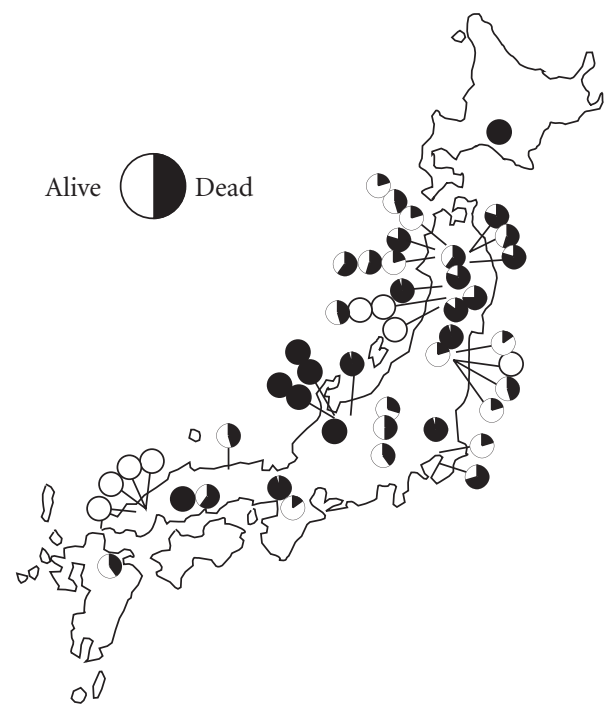

(a) Pyridaben $\left(200 \mathrm{mg} \mathrm{L}^{-1}\right)$

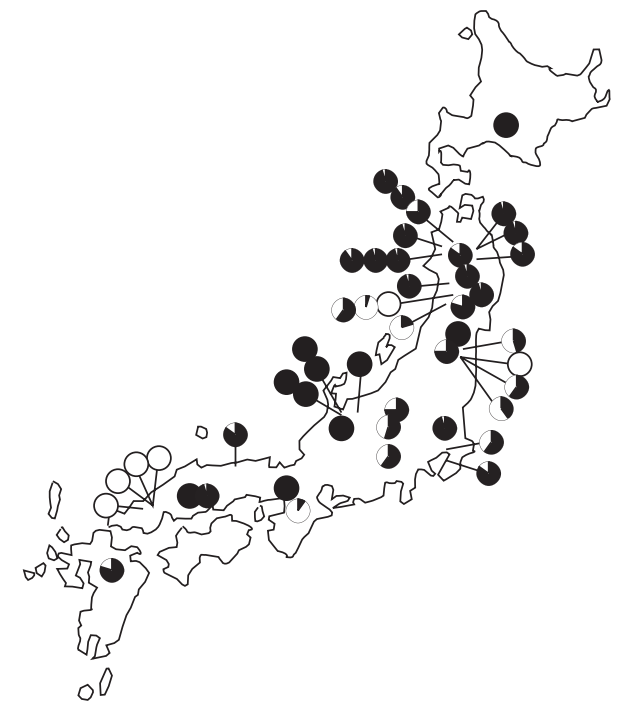

(b) Fenpyroximate $\left(50 \mathrm{mg} \mathrm{L}^{-1}\right)$

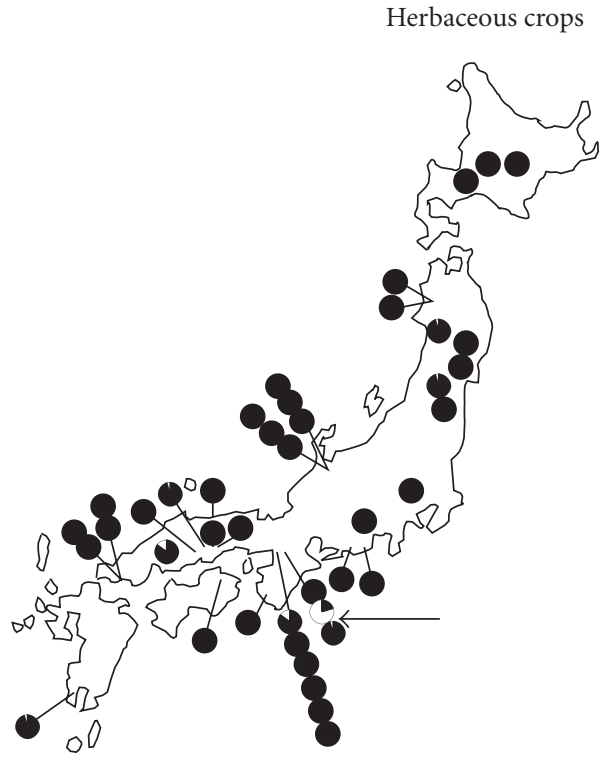

(c) Pyridaben $\left(200 \mathrm{mg} \mathrm{L}^{-1}\right)$

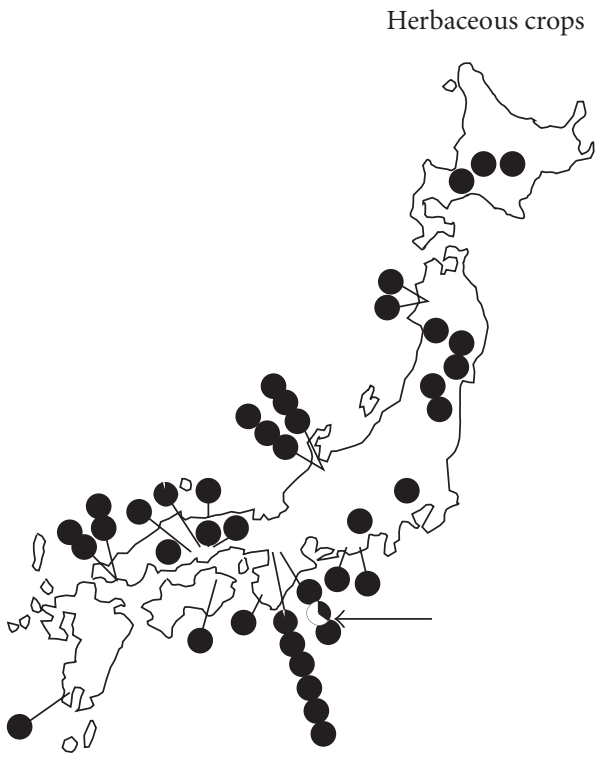

(d) Fenpyroximate $\left(50 \mathrm{mg} \mathrm{L}^{-1}\right)$

FIGURE 2: Geographic variation of susceptibility to acaricides in 48 and 42 T. urticae populations collected from woody plants (fruit trees and rose plants) (a), (b) and herbaceous crops (c), (d).

of selection and accumulation of rare genes for resistance, whereas those on herbaceous crops are unstable transients such that rare genes would be unlikely to be retained for long periods [101]. Yet, resistance to the acaricides was obviously developed in a single population on herbaceous plants (Figure 3; arrows), which could have resulted from founder effects.

In the assessment by Osakabe et al. [89], P. citri showed higher genetic diversity in acaricide resistance genes within a grove and within a tree than between groves; a two-level nested analysis of variance revealed significant difference in fenpyroximate resistance among trees within groves $(P<.025)$ but not among groves $(P>.25)$. This may reflect the population structure revealed using gene markers, as described above. Similar trends also occurred in the distribution of etoxazole resistance [89]. A variation in fenpyroximate susceptibility was found even among patches within a tree. In a field study by Yamamoto et al. [102], strong spatial aggregation of the hexythiazox resistance gene in $P$. citri was identified both between trees and within a single tree in a citrus grove. This result suggests that acaricide resistance genes are spread based on the population 


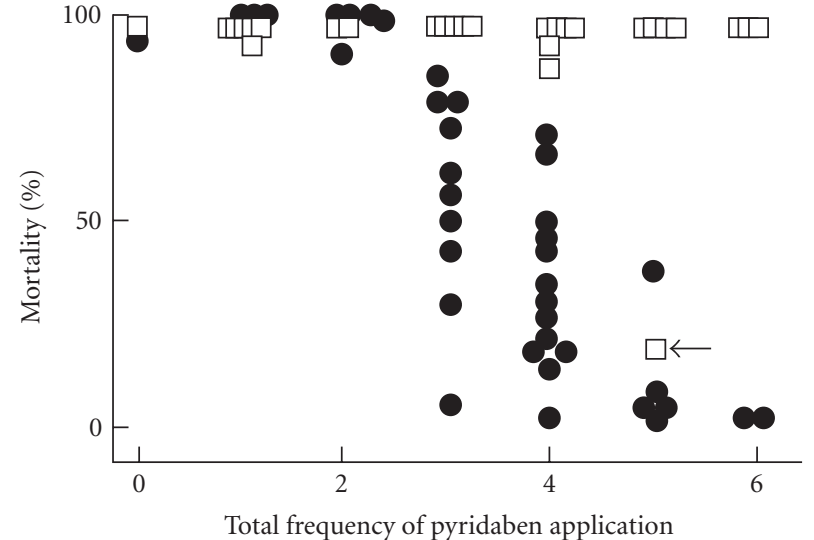

Host plants:

- Woody plants

$\square$ Herbaceous crops

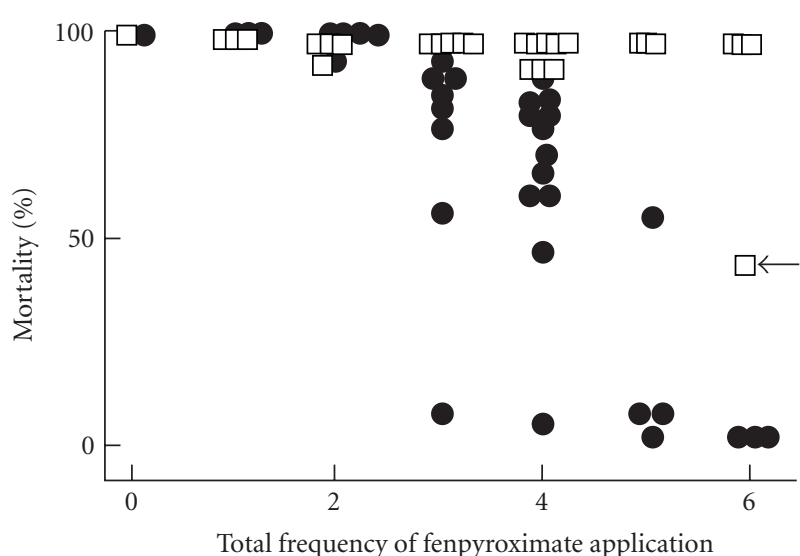

Host plants:

Woody plants

$\square$ Herbaceous crops

(a)

(b)

FIGURE 3: Correlation between total field applications of acaricides ( $200 \mathrm{mg} \mathrm{L}^{-1}$ pyridaben; $50 \mathrm{mg} \mathrm{L}^{-1}$ fenpyroximate) and mortality for local populations.

structure, that is, limited crawling dispersal within foliage [57] resulting in between-patch diversity and frequent longer aerial dispersal by ballooning resulting in between-grove homogeneity.

A study of genetic differentiation of a T. urticae population on roses in a greenhouse estimated short dispersal distances and thus low spread velocity of acaricide resistance genes [74]. Nevertheless, milbemectin resistance genes, which had been distributed only partially in the population in July 2006, spread over the bed after only 2 months (Uesugi et al. unpublished data). During those 2 months, the roses were sprayed twice with milbemectin. The mechanism of such quick resistance development is unclear. Given that gene flow among patches within a bed did not occur frequently, an increase in the gene frequencies as effects of selection likely functioned to develop resistance. As Navajas et al. [40] noted, human-promoted passive transportation through agricultural practices might facilitate the quick spread of resistance genes.

\section{Comprehensive Aspects of Acaricide Resistance Evolution}

The initial frequency of resistance genes and the gene dominance are influential factors that determine the rate of resistance development [44]. In general, given a nonstructured population, mutated alleles associated with pesticide resistance likely exist at very low frequencies, and so in most of the resistance alleles are expected to be heterozygotes. Nevertheless, theoretical model experiments have revealed that in a metapopulation condition even lower-frequency alleles form concentrated foci in a set of subpopulations with certain qualifications for selection of pesticides, extinction of subpopulations, and migration [44]. With these qualifications, subpopulation extinction and subsequent migration and reconstruction possibly occur based on incidental changes in gene frequency through founder effects. This sometimes results in the construction of subpopulations in which the resistance allele frequencies are relatively higher, making selection by pesticides more effective for resistance development.

Data concerning genetic structure suggest that spider mite populations are metapopulations. Although Uesugi et al. [87] did not find differentiation within an apple orchard, there was significant heterozygote deficiency (significantly positive $F_{I S}$ value) in all trees, suggesting that Wahlund effects may have been caused by the division of the population into small breeding patches. Young gravid females are the main dispersers of spider mites when they experience high density [83]. Whether they disperse aerially or crawl, the dispersers may arrive alone on a new feeding site. These dispersal behaviors and restricted dispersal ability by crawling imply that founder effects frequently act on spider mite colonies, promoting the development of resistance foci through selection for acaricides. The resistance genes will then spread limitedly to neighboring colonies by gene flow or colony expansion by propagation. Moreover, the resistance genes may be spread from foci to other distant habitats by aerial dispersal in each species.

We have no data about the probability of new-linkage formation among resistance genes controlled by distinctive loci on the same chromosome by recombination in field populations. The frequent occurrence of resistance foci may increase the mating chances between mites bearing different resistance genes and might be followed by the occurrence of hitchhiking effects. Precise genetic experiments will be necessary to elucidate this issue. 


\section{Acaricide Resistance Management and Globalization}

Species identification is a basic issue for biosecurity as injurious species must be identified to prevent their invasion and establishment in new areas [103-105]. Eight spider mite species including T. urticae, T. kanzawai, $P$. citri, and $P$. ulmi are serious cosmopolitan pests and are now listed as nonquarantine pests in the Plant Protection Law of Japan. Therefore, the risk of introducing exotic resistance alleles to inland areas is undoubtedly increasing. Even if there are inland populations resistant to the same acaricide, an invasion of an exotic resistance gene may be a potential risk over the long term because an introduced resistance gene would not be identical to that of inland populations. Therefore, more studies on the diversity of acaricide resistance genes should be performed using genetic marker linkage maps. Moreover, methods to control the spread of such exotic resistance genes may be important to prevent the development of more complex resistance, and mechanisms of regional dispersal and resulting gene flow may have to be addressed.

\section{Perspectives}

Identifying a mechanism for the development of pesticide resistance is important for advancing pesticide resistance management for arthropod pests. In spider mites, past genetic and ecological studies have comprehensively suggested that the local concentration of resistance genes (increasing gene frequency in breeding patches) resulting from genetic diversity within habitats based on their biological traits and selection by acaricides and gene flow from selection sites to surroundings (local and/or regional spread of resistance) are the processes of acaricide resistance evolution.

Our study has revealed the consequences of habitat stability to acaricide resistance development [101] and implies that disturbing the expansion of incipient colonies is effective for restraining acaricide resistance development and avoiding complications with spider mites. Although natural enemies such as phytoseiid mites (Acari: Phytoseiidae) play the role of the disturber, their settlement and predation activity are important. We expect the development of new technologies for the management of natural enemies, such as artificial diet provisions [106]. Other factors possibly disturbing incipient spider mite colonies such as ultraviolet rays, which are lethal to spider mites [107], should also be exploited. Overall, the establishment of an integrated mite management strategy aimed at lowering spider mite population density may be the best way to manage acaricide resistance.

\section{References}

[1] M. E. Whalon, D. Mota-Sanchez, and R. M. Hollingworth, "Analysis of global pesticide resistance in arthropods," in Global Pesticide Resistance in Arthropods, M. E. Whalon, D. Mota-Sanchez, and R. M. Hollingworth, Eds., pp. 5-31, CABI, Oxfordshire, UK, 2008.
[2] R. M. Hollingworth and K. Dong, "The biochemical and molecular genetic basis of resistance to pesticides in arthropods," in Global Pesticide Resistance in Arthropods, M. E. Whalon, D. Mota-Sanchez, and R. M. Hollingworth, Eds., pp. 40-89, CABI, Oxfordshire, UK, 2008.

[3] Y.-S. Lee, M.-H. Song, K.-S. Ahn, K.-Y. Lee, J.-W. Kim, and G.-H. Kim, "Monitoring of acaricide resistance in two-spotted spider mite (Tetranychus urticae) populations from rose greenhouses in Korea," Journal of Asia-Pacific Entomology, vol. 6, no. 1, pp. 91-96, 2003.

[4] T. Van Leeuwen, S. Van Pottelberge, and L. Tirry, "Comparative acaricide susceptibility and detoxifying enzyme activities in field-collected resistant and susceptible strains of Tetranychus urticae," Pest Management Science, vol. 61, no. 5, pp. 499-507, 2005.

[5] D. J. Pree, K. J. Whitty, and L. Van Driel, "Baseline susceptibility and cross resistances of some new acaricides in the European red mite, Panonychus ulmi," Experimental and Applied Acarology, vol. 37, no. 3-4, pp. 165-171, 2005.

[6] G. P. Georghiou and C. E. Taylor, "Genetic and biological influences in the evolution of insecticide resistance," Journal of Economic Entomology, vol. 70, no. 3, pp. 319-323, 1977.

[7] G. P. Georghiou and C. E. Taylor, "Operational influences in the evolution of insecticide resistance," Journal of Economic Entomology, vol. 70, no. 5, pp. 653-658, 1977.

[8] I. Denholm and M. W. Rowland, "Tactics for managing pesticide resistance in arthropods: theory and practice," Annual Review of Entomology, vol. 37, no. 1, pp. 91-112, 1992.

[9] S. Lee, K. Ahn, C. Kim, S. Shin, and G. Kim, "Inheritance and stability of etoxazole resistance in twospotted spider mite, Tetranychus urticae, and its cross resistance," Korean Journal of Applied Entomology, vol. 43, pp. 43-48, 2004.

[10] M. Asahara, R. Uesugi, and Mh. Osakabe, "Linkage between one of the polygenic hexythiazox resistance genes and an etoxazole resistance gene in the twospotted spider mite (Acari: Tetranychidae)," Journal of Economic Entomology, vol. 101, no. 5, pp. 1704-1710, 2008.

[11] G. A. Herron and J. Rophail, "Genetics of hexythiazox resistance in two spotted spider mite, Tetranychus urticae Koch," Experimental and Applied Acarology, vol. 17, no. 6, pp. 423-431, 1993.

[12] T. Van Leeuwen, V. Stillatus, and L. Tirry, "Genetic analysis and cross-resistance spectrum of a laboratory-selected chlorfenapyr resistant strain of two-spotted spider mite (Acari: Tetranychidae)," Experimental and Applied Acarology, vol. 32, no. 4, pp. 249-261, 2004.

[13] T. Van Leeuwen, S. Van Pottelberge, and L. Tirry, "Biochemical analysis of a chlorfenapyr-selected resistant strain of Tetranychus urticae Koch," Pest Management Science, vol. 62, no. 5, pp. 425-433, 2006.

[14] R. Uesugi, K. Goka, and Mh. Osakabe, "Genetic basis of resistances to chlorfenapyr and etoxazole in the two-spotted spider mite (Acari: Tetranychidae)," Journal of Economic Entomology, vol. 95, no. 6, pp. 1267-1274, 2002.

[15] G. Herron, V. Edge, and J. Rophail, "Clofentezine and hexythiazox resistance in Tetranychus urticae Koch in Australia," Experimental and Applied Acarology, vol. 17, no. 6, pp. 433-440, 1993.

[16] M. Kobayashi, S. Kobayashi, and T. Nishimori, "Occurrence of etoxazole resistance individuals of the two-spotted spider mite, Tetranychus urticae Koch from a limited region," Japanese Journal of Applied Entomology and Zoology, vol. 45, no. 2, pp. 83-88, 2001 (Japanese). 
[17] T. Ishida, J. Suzuki, and Y. Tsukidate, "YI-5301, a novel oxazoline acaricide," in Proceedings of the British Crop Protection Conference on Pests \& Diseases, vol. 2, pp. 37-44, 1994.

[18] R. Nauen and G. Smagghe, "Mode of action of etoxazole," Pest Management Science, vol. 62, no. 5, pp. 379-382, 2006.

[19] R. T. Roush and J. A. McKenzie, "Ecological genetics of insecticide and acaricide resistance," Annual Review of Entomology, vol. 32, pp. 361-380, 1987.

[20] J. A. McKenzie, A. G. Parker, and J. L. Yen, "Polygenic and single gene responses to selection for resistance to diazinon in Lucilia cuprina," Genetics, vol. 130, no. 3, pp. 613-620, 1992.

[21] Y. Carrière and D. A. Roff, "Change in genetic architecture resulting from the evolution of insecticide resistance: a theoretical and empirical analysis," Heredity, vol. 75, no. 6, pp. 618-629, 1995.

[22] T. E. Martinson, T. J. Dennehey, J. P. Nyrop, and W. H. Reissig, "Field-measurements of selection for twospotted spider mite (Acari: Tetranychidae) resistance to dicofol in apple orchards," Journal of Economic Entomology, vol. 84, pp. 7-16, 1991.

[23] A. Yamamoto, H. Yoneda, R. Hatano, and M. Asada, "Genetic analysis of hexythiazox resistance in the citrus red mite, Panonychus citri (McGregor)," Journal of Pesticide Science, vol. 20, pp. 513-519, 1995.

[24] K. Goka, "Mode of inheritance of resistance to three new acaricides in the Kanzawa spider mite, Tetranychus kanzawai Kishida (Acari: Tetranychidae)," Experimental and Applied Acarology, vol. 22, no. 12, pp. 699-708, 1998.

[25] A. Mizutani, F. Kumayama, K. Ohba, T. Ishiguro, and Y. Hayashi, "Inheritance of resistance to cyhexatin in the Kanzawa spider mite, Tetranychus kanzawai Kishida (Acarina: Tetranychidae)," Applied Entomology and Zoology, vol. 23, pp. 251-255, 1988.

[26] M. A. Keena and J. Granett, "Genetic analysis of propargite resistance in Pacific spider mites and twospotted spider mites (Acari: Tetranychidae)," Journal of Economic Entomology, vol. 83, pp. 655-661, 1990.

[27] J. M. Clark, J. G. Scott, F. Campos, and J. R. Bloomquist, "Resistance to avermectins: extent, mechanisms, and management implications," Annual Review of Entomology, vol. 40, pp. 1-30, 1995.

[28] W. Helle and L. P. Pijnacker, "Parthenogenesis, chromosomes and sex," in Spider Mites. Their Biology, Natural Enemies and Control. Vol. 1A, W. Helle and M. W. Sabelis, Eds., pp. 129139, Elsevier, Amsterdam, The Netherlands, 1985.

[29] L. J. Lester and R. K. Selander, "Population genetics of haplodiploid insects," Genetics, vol. 92, no. 4, pp. 1329-1345, 1979.

[30] R. H. Crozier, "Adaptive consequences of male-haploidy," in Spider Mites. Their Biology, Natural Enemies and Control. Vol. 1A, W. Helle and M. W. Sabelis, Eds., pp. 201-222, Elsevier, Amsterdam, The Netherlands, 1985.

[31] Y. Carrière, "Haplodiploidy, sex, and the evolution of pesticide resistance," Journal of Economic Entomology, vol. 96, no. 6, pp. 1626-1640, 2003.

[32] D. W. Crowder, Y. Carrière, B. E. Tabashnik, P. C. Ellsworth, and T. J. Dennehy, "Modeling evolution of resistance to pyriproxyfen by the sweetpotato whitefly (Homoptera: Aleyrodidae)," Journal of Economic Entomology, vol. 99, no. 4, pp. 1396-1406, 2006.

[33] P. Pamilo and R. H. Crozier, "Genetic variation in male haploids under deterministic selection," Genetics, vol. 98, pp. 199-214, 1981.
[34] K. Kojima and H. E. Schaffer, "Survival process of linked mutant genes," Evolution, vol. 21, pp. 518-538, 1967.

[35] J. Maynard-Smith and J. Haigh, "The hitch-hiking effect of a favorable gene," Genetics Research, vol. 23, pp. 23-35, 1974.

[36] K. Goka and A. Takafuji, "Genetic basis of esterase, malate dehydrogenase and phosphoglucoisomerase allozymes in the two-spotted spider mite, Tetranychus urticae Koch," Applied Entomology and Zoology, vol. 30, pp. 529-535, 1995.

[37] G. Yan, D. D. Chadee, and D. W. Severson, "Evidence for genetic hitchhiking effect associated with insecticide resistance in Aedes aegypti," Genetics, vol. 148, no. 2, pp. 793800, 1998.

[38] Mh. Osakabe, N. Hinomoto, S. Toda, S. Komazaki, and K. Goka, "Molecular cloning and characterization of a microsatellite locus found in an RAPD marker of a spider mite, Panonychus citri (Acari: Tetranychidae)," Experimental and Applied Acarology, vol. 24, no. 5-6, pp. 385-395, 2000.

[39] M. J. Navajas, H. M. A. Thistlewood, J. Lagnel, and C. Hughes, "Microsatellite sequences are under-represented in two mite genomes," Insect Molecular Biology, vol. 7, no. 3, pp. 249-256, 1998.

[40] M. Navajas, M. J. Perrot-Minnot, J. Lagnel, A. Migeon, T. Bourse, and J. M. Cornuet, "Genetic structure of a greenhouse population of the spider mite Tetranychus urticae: spatio-temporal analysis with microsatellite markers," Insect Molecular Biology, vol. 11, no. 2, pp. 157-165, 2002.

[41] R. Uesugi and Mh. Osakabe, "Isolation and characterization of microsatellite loci in the two-spotted spider mite, Tetranychus urticae (Acari: Tetranychidae)," Molecular Ecology Notes, vol. 7, no. 2, pp. 290-292, 2007.

[42] S. Nishimura, N. Hinomoto, and A. Takafuji, "Isolation, characterization, inheritance and linkage of microsatellite markers in Tetranychus kanzawai (Acari: Tetranychidae)," Experimental and Applied Acarology, vol. 31, no. 1-2, pp. 93103, 2003.

[43] X. Bailly, A. Migeon, and M. Navajas, "Analysis of microsatellite variation in the spider mite pest Tetranychus turkestani (Acari: Tetranychidae) reveals population genetic structure and raises questions about related ecological factors," Biological Journal of the Linnean Society, vol. 82, no. 1, pp. 69-78, 2004.

[44] P. A. Follett and G. K. Roderick, "Adaptation to insecticides in Colorado potato beetle: single- and meta-population models," in Chrysomelidae Biology, P. H. A. Jolivet and M. L. Cox, Eds., vol. 4, pp. 289-302, SPB Academic, Amsterdam, The Netherlands, 1996.

[45] L. Jeppson, H. H. Keifer, and E. W. Baker, Mites Injurious to Economic Plants, University of California Press, Berkeley, Calif, USA, 1975.

[46] G. G. Kennedy and D. R. Smitley, "Dispersal," in Spider Mites. Their Biology, Natural Enemies and Control. Vol. 1A, W. Helle and M. W. Sabelis, Eds., pp. 233-242, Elsevier, Amsterdam, The Netherlands, 1985.

[47] Mh. Osakabe, H. Isobe, A. Kasai, R. Masuda, S. Kubota, and M. Umeda, "Aerodynamic advantages of upside down take-off for aerial dispersal in Tetranychus spider mites," Experimental and Applied Acarology, vol. 44, no. 3, pp. 165183, 2008.

[48] W. Helle, "Genetics of resistance to organophophorus compounds and its relation to diapause in Tetranychus urticae Koch," Tijdschrift over Plantenziekten, vol. 68, pp. 1-41, 1962.

[49] N. W. Hussey and W. J. Parr, "Dispersal of the glasshouse red spider mite Tetranychus urticae Koch (Acarina, Tetranychidae)," Entomologia Experimentalis et Applicata, vol. 6, no. 3, pp. 207-214, 1963. 
[50] G. Nachman, "Temporal and spatial dynamics of an acarina predator-prey system," Journal of Animal Ecology, vol. 50, pp. 433-451, 1981.

[51] A. Kondo and A. Takafuji, "Resource utilization pattern of two species of tetranychid mites (Acarina: Tetranychidae)," Researches on Population Ecology, vol. 27, no. 1, pp. 145-157, 1985.

[52] P.-M. So, "Distribution patterns of and sampling plans for Tetranychus urticae Koch (Acarina: Tetranychidae) on roses," Researches on Population Ecology, vol. 33, no. 2, pp. 229-243, 1991.

[53] N. Hinomoto and A. Takafuji, "Studies on the population structure of the two-spotted spider mite, Tetranychus urticae Koch, by allozyme variability analysis," Applied Entomology and Zoology, vol. 29, no. 2, pp. 259-266, 1994.

[54] N. Hinomoto and A. Takafuji, "Genetic changes in the population structure of the two-spotted spider mite, Tetranychus urticae Koch (Acari: Tetranychidae) on vinyl-house strawberries," Applied Entomology and Zoology, vol. 30, pp. 521-528, 1995.

[55] S. Wright, Evolution and the Genetics of Populations. Vol. 4. Variability within and among Natural Popuolations, The University of Chicago Press, Chicago, Ill, USA, 1978.

[56] K. Wanibuchi and Y. Saito, "The process of population increase and patterns of resource utilization of two spider mites, Oligonychus ununguis (Jacobi) and Panonychus citri (McGregor), under experimental conditions (Acari: Tetranychidae)," Researches on Population Ecology, vol. 25, no. 1, pp. 116-129, 1983.

[57] Mh. Osakabe and S. Komazaki, "Laboratory experiments on a change in genetic structure with an increase of population density in the citrus red mite population, Panonychus citri (McGregor) (Acari: Tetranychidae)," Applied Entomology and Zoology, vol. 34, no. 4, pp. 413-420, 1999.

[58] Mh. Osakabe, "Genetic analysis of esterases in the citrus red mite, Panonychus citri (McGregor) (Acari: Tetranychidae)," Applied Entomology and Zoology, vol. 26, pp. 307-312, 1991.

[59] W. Helle and W. P. J. Overmeer, "Variability in tetranychid mites," Annual Review of Entomology, vol. 18, pp. 97-120, 1973.

[60] D. A. Potter and D. L. Wrensch, "Interrupted matings and the effectiveness of second inseminations in the twospotted spider mite," Annals of the Entomological Society of America, vol. 71, pp. 882-885, 1978.

[61] A. Takafuji, "Effectiveness of second mating for two incompatible types of the citrus red mite, Panonychus citri (McGregor)," Researches on Population Ecology, vol. 28, no. 1, pp. 91101, 1986.

[62] R. Uesugi, K. Goka, and Mh. Osakabe, "Development of genetic differentiation and postzygotic isolation in experimental metapopulations of spider mites," Experimental and Applied Acarology, vol. 31, no. 3-4, pp. 161-176, 2003.

[63] E. E. Grafton-Cardwell, J. Granett, and S. M. Normington, "Influence of dispersal from almonds on the population dynamics and acaricide resistance frequencies of spider mites infesting neighboring cotton," Experimental and Applied Acarology, vol. 10, no. 3-4, pp. 187-212, 1991.

[64] F. V. Sances, J. A. Wyman, and I. P. Ting, "Physiological responses to spider mite infestations on strawberries," Environmental Entomology, vol. 8, pp. 711-714, 1979.

[65] J. D. De Angelis, K. C. Larson, R. E. Berry, and G. W. Krantz, "Effects of spider mite injury on transpiration and leaf water status in peppermint," Environmental Entomology, vol. 11, pp. 975-978, 1982.
[66] R. L. Brandenburg and G. G. Kennedy, "Intercrop relationships and spider mite dispersal in a corn/peanut agroecosystem," Entomologia Experimentalis et Applicata, vol. 32, no. 3, pp. 269-276, 1982.

[67] D. R. Smitley and G. G. Kennedy, "Aerial dispersal of the twospotted spider mite (Tetranychus urticae) from field corn," Experimental and Applied Acarology, vol. 5, no. 1-2, pp. 3346, 1988.

[68] D. S. Lawson, J. P. Nyrop, and T. J. Dennehy, "Aerial dispersal of European red mites (Acari: Tetranychidae) in commercial apple orchards," Experimental and Applied Acarology, vol. 20, no. 4, pp. 193-202, 1996.

[69] K. Goka and A. Takafuji, "Allozyme variations among populations of the two-spotted spider mite, Tetranychus urticae Koch, in Japan," Applied Entomology and Zoology, vol. 30, pp. 567-579, 1995.

[70] A. Tsagkarakou, M. Navajas, F. Rousset, and N. Pasteur, "Genetic differentiation in Tetranychus urticae (Acari: Tetranychidae) from greenhouses in France," Experimental and Applied Acarology, vol. 23, no. 5, pp. 365-378, 1999.

[71] L. S. Boykin and W. V. Campbell, "Wind dispersal of the twospotted spider mite (Acari: Tetranychidae) in North Carolina peanut fields," Environmental Entomology, vol. 13, pp. 221-227, 1984.

[72] D. R. Smitley and G. G. Kennedy, "Photo-oriented aerialdispersal behavior of Tetranychus urticae (Acari: Tetranychidae) enhances escape from the leaf surface," Annals of the Entomological Society of America, vol. 78, pp. 609-614, 1985.

[73] D. C. Margolies, "Conditions eliciting aerial dispersal behavior in banks grass mite, Oligonychus pratensis (Acari: Tetranychidae)," Environmental Entomology, vol. 16, pp. 928-932, 1987.

[74] R. Uesugi, Y. Kunimoto, and Mh. Osakabe, "The fine-scale genetic structure of the two-spotted spider mite in a commercial greenhouse," Experimental and Applied Acarology, vol. 47, no. 2, pp. 99-109, 2009.

[75] B. S. Weir and C. C. Cockerham, "Estimating F-statistics for the analysis of population structure," Evolution, vol. 38, no. 6, pp. 1358-1370, 1984.

[76] P. A. Fuerst and T. Maruyama, "Considerations on the conservation of alleles and of genic heterozygosity in small managed populations," Zoo Biology, vol. 5, pp. 171-180, 1986.

[77] M. Gilpin, "The genetic effective size of a metapopulation," Biological Journal of the Linnean Society, vol. 42, no. 1-2, pp. 165-175, 1991.

[78] S. Wright, "Isolation by distance," Genetics, vol. 28, pp. 114$138,1943$.

[79] F. Rousset, "Genetic differentiation and estimation of gene flow from $F$-statistics under isolation by distance," Genetics, vol. 145, no. 4, pp. 1219-1228, 1997.

[80] P. E. Smouse and R. Peakall, "Spatial autocorrelation analysis of individual multiallele and multilocus genetic structure," Heredity, vol. 82, no. 5, pp. 561-573, 1999.

[81] S. Yano, "Collective and solitary behaviors of twospotted spider mite (Acari: Tetranychidae) are induced by trail following," Annals of the Entomological Society of America, vol. 101, no. 1, pp. 247-252, 2008.

[82] C. A. Fleschner, M. E. Badgley, D. W. Ricker, and J. C. Hall, "Air drift of spider mites," Journal of Economic Entomology, vol. 49, pp. 624-627, 1956.

[83] R. Mitchell, "Growth and population dynamics of a spider mite (Tetranychus urticae K., Acarina: Tetranychidae)," Ecology, vol. 54, pp. 1349-1355, 1973. 
[84] C. Jung and B. A. Croft, "Aerial dispersal of phytoseiid mites (Acari: Phytoseiidae): estimating falling speed and dispersal distance of adult females," Oikos, vol. 94, no. 1, pp. 182-190, 2001.

[85] D. H. Janzen, "Herbivores and the number of tree species in tropical forests," The American Naturalist, vol. 104, pp. 501$528,1970$.

[86] A. Takafuji and N. Morimoto, "Diapause attributes and seasonal occurrences of two populations of the citrus red mite, Panonychus citri (McGregor) on pear (Acarina: Tetranychidae)," Applied Entomology and Zoology, vol. 18, pp. 525-532, 1983.

[87] R. Uesugi, T. Sasawaki, and Mh. Osakabe, "Evidence of a high level of gene flow among apple trees in Tetranychus urticae," Experimental and Applied Acarology, vol. 49, no. 4, pp. 281290, 2009.

[88] A. Tsagkarakou, M. Navajas, P. Papaioannou-Souliotis, and N. Pasteur, "Gene flow among Tetranychus urticae (Acari: Tetranychidae) populations in Greece," Molecular Ecology, vol. 7, no. 1, pp. 71-79, 1998.

[89] Mh. Osakabe, K. Goka, S. Toda, T. Shintaku, and H. Amano, "Significance of habitat type for the genetic population structure of Panonychus citri (Acari: Tetranychidae)," Experimental and Applied Acarology, vol. 36, no. 1, pp. 25-40, 2005.

[90] M. Nei, "Analysis of gene diversity in subdivided populations," Proceedings of the National Academy of Sciences of the United States of America, vol. 70, no. 12, pp. 3321-3323, 1973.

[91] R. Chakraborty, "Gene-diversity analysis in nested subdivided populations," Genetics, vol. 96, pp. 721-726, 1980.

[92] Mh. Osakabe and Y. Sakagami, "Protein differences detected by two-dimensional electrophoresis among local populations of Panonychus citri (McGregor) (Acari: Tetranychidae) in Japan," Applied Entomology and Zoology, vol. 28, no. 4, pp. 497-502, 1993.

[93] A. Tsagkarakou, M. Navajas, J. Lagnel, and N. Pasteur, "Population structure in the spider mite Tetranychus urticae (Acari: Tetranychidae) from Crete based on multiple allozymes," Heredity, vol. 78, no. 1, pp. 84-92, 1997.

[94] D. F. Greene and E. A. Johnson, "A model of wind disperal of winged or plumed seeds," Ecology, vol. 70, no. 2, pp. 339-347, 1989.

[95] A. Okubo and S. A. Levin, "A theoretical framework for data analysis of wind dispersal of seeds and pollen," Ecology, vol. 70, no. 2, pp. 329-338, 1989.

[96] R. Beckwitt and R. Chakraborty, "Genetic structure of Pileolaria pseudomilitaris (Polychaeta: Spirorbidae)," Genetics, vol. 96, no. 3, pp. 711-726, 1980.

[97] P. Franck, M. Reyes, J. Olivares, and B. Sauphanor, "Genetic architecture in codling moth populations: comparison between microsatellite and insecticide resistance markers," Molecular Ecology, vol. 16, no. 17, pp. 3554-3564, 2007.

[98] B. E. Tabashnik and B. A. Croft, "Managing pesticide resistance crop-arthropod complexes: interactions between biological and operational factors," Environmental Entomology, vol. 11, pp. 1137-1144, 1982.

[99] M. A. Caprio and B. E. Tabashnik, "Gene flow accelerates local adaptation among finite populations: simulating the evolution of insecticide resistance," Journal of Economic Entomology, vol. 85, pp. 611-620, 1992.

[100] J. E. Dunley and B. A. Croft, "Gene flow measured by allozymic analysis in pesticide resistant Typhlodromus pyri occurring within and near apple orchards," Experimental and Applied Acarology, vol. 18, no. 4, pp. 201-211, 1994.
[101] K. Goka, "The effect of patch size and persistence of host plants on the development of acaricide resistance in the twospotted spider mite Tetranychus urticae (Acari: Tetranychidae)," Experimental and Applied Acarology, vol. 23, no. 5, pp. 419-427, 1999.

[102] A. Yamamoto, H. Yoneda, R. Hatano, and M. Asada, "Field selection experiments with hexythiazox in the citrus red mite, Panonychus citri (McGregor)," Journal of Pesticide Science, vol. 20, pp. 307-315, 1995.

[103] Mh. Osakabe, T. Hirose, and M. Sato, "Discrimination of four Japanese Tetranychus species (Acari: Tetranychidae) using PCR-RFLP of the inter-transcribed spacer region of nuclear ribosomal DNA," Applied Entomology and Zoology, vol. 37, no. 3, pp. 399-407, 2002.

[104] Mh. Osakabe, Y. Kotsubo, R. Tajima, and N. Hinomoto, "Restriction fragment length polymorphism catalogue for molecular identification of Japanese Tetranychus spider mites (Acari: Tetranychidae)," Journal of Economic Entomology, vol. 101, pp. 1167-1175, 2008.

[105] L. A. Meyerson and J. K. Reaser, "Biosecurity: moving toward a comprehensive approach," BioScience, vol. 52, no. 7, pp. 593-600, 2002.

[106] Y. Ogawa and Mh. Osakabe, "Development, long-term survival, and the maintenance of fertility in Neoseiulus californicus (Acari: Phytoseiidae) reared on an artificial diet," Experimental and Applied Acarology, vol. 45, no. 3-4, pp. 123136, 2008.

[107] K. Ohtsuka and Mh. Osakabe, "Deleterious effects of UV$\mathrm{B}$ radiation on herbivorous spider mites: they can avoid it by remaining on lower leaf surfaces," Environmental Entomology, vol. 38, no. 3, pp. 920-929, 2009. 

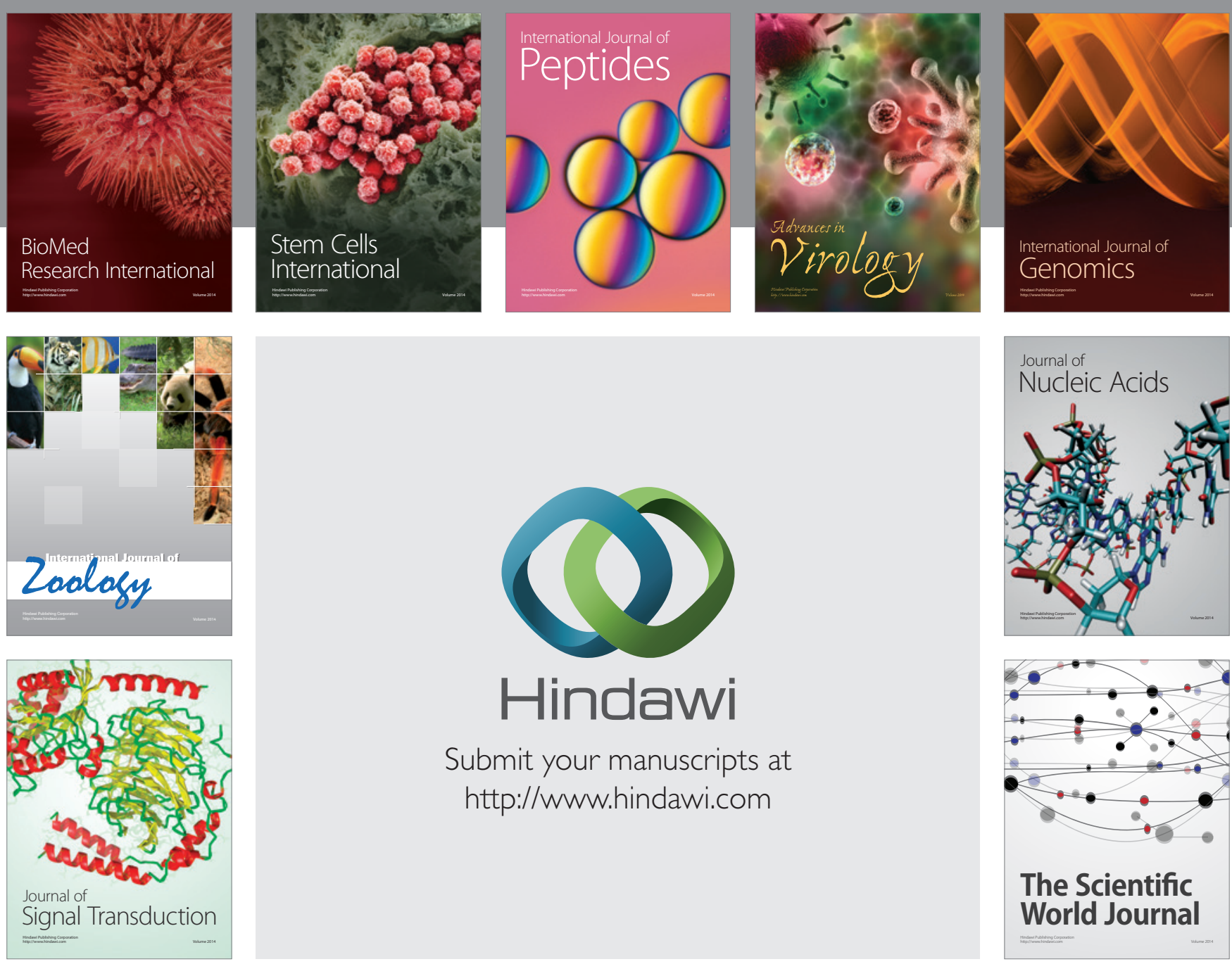

Submit your manuscripts at

http://www.hindawi.com
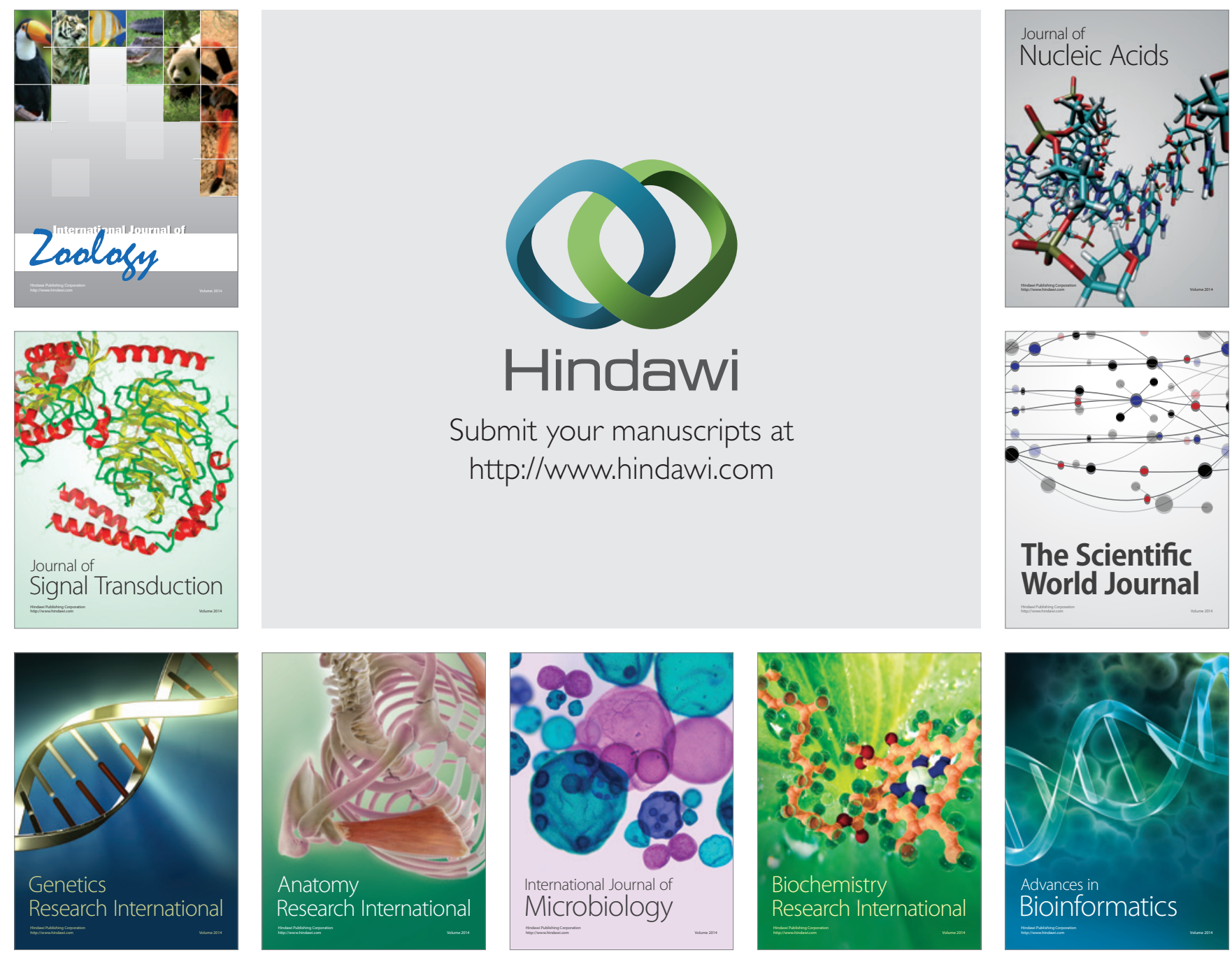

The Scientific World Journal
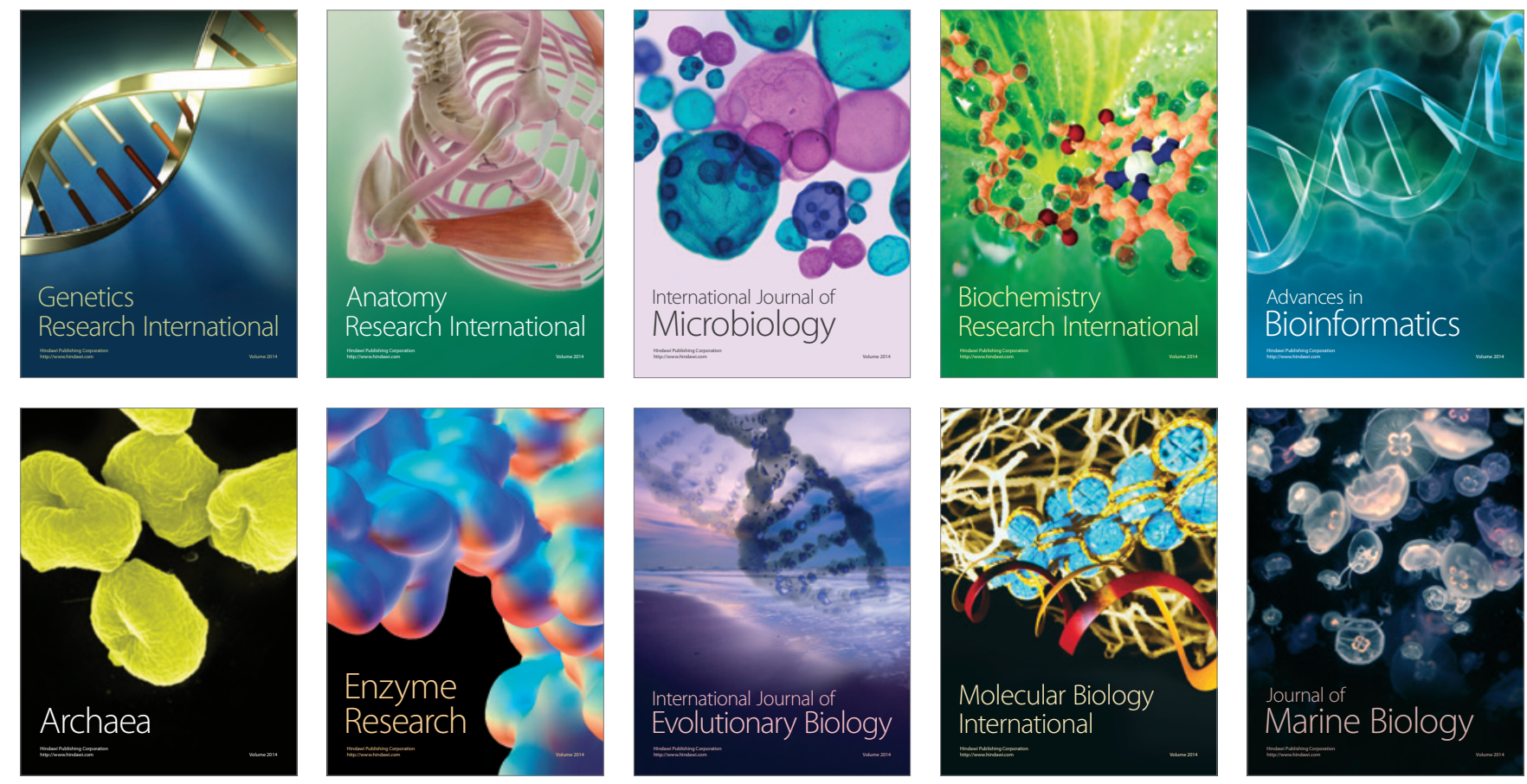